\title{
Uropathogens and antimicrobial susceptibility profiles of asymptomatic bacteriuria among pregnant women receiving antenatal care in traditional birth attendants homes in Ikono, Akwa- Ibom State, Nigeria
}

\author{
Anthony John Umoyen ${ }^{1 *}$, Nseobong Godwin Akpan²,3, Cecilia James Sunday, \\ Blessing Bassey Ekpenyong ${ }^{1}$
}

\begin{abstract}
${ }^{1}$ Human Genetics and Biotechnology Unit, Department of Genetics and Biotechnology, Faculty of Biological Sciences, University of Calabar, Calabar, Nigeria

${ }^{2}$ Department of Medical Microbiology and Parasitology, Faculty of Clinical Sciences, University of Uyo, Uyo, Nigeria ${ }^{3}$ Medical Microbiology Unit, Department of Medical Laboratory Science, Faculty of Allied Medical Sciences, University of Calabar, Calabar, Nigeria
\end{abstract}

Received: 24 January 2021

Accepted: 02 March 2021

\section{*Correspondence:}

Dr. Anthony John Umoyen,

E-mail: anthonyumoyen4000@gmail.com

Copyright: (C) the author(s), publisher and licensee Medip Academy. This is an open-access article distributed under the terms of the Creative Commons Attribution Non-Commercial License, which permits unrestricted non-commercial use, distribution, and reproduction in any medium, provided the original work is properly cited.

\section{ABSTRACT}

Background: Asymptomatic bacteriuria (ASB) in pregnancy is associated with adverse maternal and obstetric outcomes if untreated. The aim of this study was to determine the prevalence and susceptibility profile of ASB among pregnant women attending antenatal clinics in traditional birth attendant homes in Ikono, Akwa-Ibom State.

Methods: The study was a cross sectional survey using 350 pregnant women with ASB. Mid-stream clean catch urine samples were collected from the women using sterile containers. The urine samples were cultured, bacterial colonies were identified and antibiotic sensitivity was done. Data was analyzed using SPSS version 20.0 and significant was set at $\leq 0.05$.

Results: The overall prevalence was $33.4 \%$ using 350 asymptomatic pregnant women. The mean age was $26.21 \pm 3.6$ years and aged 27-32 have the highest prevalence (13.4) of ASB. 55.1\% attained primary school, while $33.4 \%$ had informal education, monoparous $(54 \%), 3^{\text {rd }}$ trimester was $44.6 \%$ with $15.8 \%$ positive cases. Multigravidae was $71.1 \%$ with $19.4 \%$ positive cases. There was significant association of age, education, parity, occupation, monthly income, etc with ASB. The most common isolates were Escherichia coli (29.9\%), then Klebsiella pneumonia (19.7\%). Pseudomonas aeruginosa was susceptible to gentamicin (92\%), Ciprofloxacin (83\%) imipenam (83\%) and azetronam (75\%), while Staphylococcus saprophyticus was susceptible to imipenam (90\%), then gentamicin at $80 \%$. Multi-drug resistant were widespread in most of the isolates.

Conclusions: Multi-drug resistant were observed in most of the isolates. Continuous and collaborative surveillance of ASB and antimicrobial resistance pattern are essential to reduce the consequence of asymptomatic bacteriuria in pregnant women.

Keywords: Asymptomatic bacteriuria, Prevalence, Susceptibility profile, Traditional birth attendants, Uropathogens

\section{INTRODUCTION}

Urinary tract infections (UTI) are one of the most common bacterial infections that occurs in humans; especially during pregnancy. ${ }^{1}$ If left untreated, UTI could lead to maternal and perinatal morbidity and mortality. ${ }^{1,2}$
UTI may be asymptomatic or symptomatic, which often makes diagnosis difficult. In a large number of patients, UTIs are preceded by asymptomatic bacteriuria (ASB). ${ }^{1,3}$ Bacteriuria during pregnancy is associated with a low birthweight and premature delivery. ${ }^{4}$ The varying prevalence of UTI in pregnancy have been reported 
globally. ${ }^{5-7}$ Asymptomatic bacteriuria during pregnancy may lead to both maternal and obstetric outcomes like pyelonephritis, cystitis and when not medically treated adequately. ${ }^{5,6}$ Researches have shown that the incidence of asymptomatic bacteriuria (ASB) in pregnant women ranges from $3.5 \%$ to $55 \%$; where higher incidence occurred in developing countries. ${ }^{7-10}$ The development of resistance to previously effective antibiotics by common uropathogens has been reported globally in the past few years. $^{7-8}$

Traditional birth attendants (TBAs) are individuals; either skills or unskilled who assist women in childbirth and also provide care during pregnancy, labour, postnatal period and give advice about childcare. ${ }^{11}$ Hence they may be labeled 'traditional midwife'. ${ }^{11}$ In country like Gambia, TBAs are an integral part of the primary healthcare system. ${ }^{11,12}$ In contrast, trained TBAs are individuals who have received short course(s) training to enhance their skills and knowledge through the modern health care sector or institution. ${ }^{13}$ However, it may be challenging for community members to differentiate trained TBAs from untrained TBAs. Births assisted by TBAs and other untrained personnel are common in some population; especially in rural settings. ${ }^{14-15}$

In Nigeria and other west African countries, the choice to deliver outside hospital settings could be motivated by different factors like physical, social, economic, cultural reason, etc. ${ }^{14}$ According to documented studies, it was estimated that $60 \%-80 \%$ of all deliveries in developing countries occur outside modern health care facilities, with a reasonable proportion of these attended by TBAs. ${ }^{14-16}$ Researches have showed that although rural women may have registered for prenatal care in government owned health care facilities, approximately half of them delivered at home under the care of TBAs. ${ }^{15,16}$ In Nigeria, a good proportion of indigenous women patronize religious and traditional birth homes for antenatal care. ${ }^{15-}$ 17 Antenatal education promotes better pregnancy outcome and care for neonates. ${ }^{18,19}$ This service is poor in traditional birth attendant homes; especially the untrained TBAs. $^{20}$ The traditional birth attendants have been reported to be largely uneducated, and cannot pass valuable information on disease prevention to their clients. ${ }^{20}$ Studies have shown in developing countries that a woman's level of education is a major determinant factor of her health seeking behavior. ${ }^{21,22}$ Poverty and low educational status have associated with patronage and delivery of pregnant women by traditional birth attendants. $^{7,10-13,23}$ These factors have also been shown to be associated with ASB infection in pregnant women. ${ }^{9,13}$ Numerous research on prevalence of asymptomatic urinary tract infection among pregnant women in Akwa Ibom, Nigeria are availablebut to the best of our knowledge, none have focused on pregnant women receiving ante-natal care in traditional birth attendant homes. ${ }^{10,25,26}$ Additionally, the health status of pregnant woman attending unorthodox birth centers (traditional and religious birth attendant homes) in villages within
Akwa Ibom state has been neglected and researches have shown that reasonable number of pregnant women in the country deliver their babies outside modern health facilities. ${ }^{9,14,16,17,24}$ There is paucity of documented research on the prevalence of uropathogens and antimicrobial susceptibility profiles of ASB among pregnant women receiving antenatal care in traditional birth attendant homes in Ikono, Akwa Ibom State, Nigeria. Therefore this research seek to investigate on the prevalence, risk factors, etiologic agents and susceptibility profile of ASB among pregnant women attending antenatal clinics in traditional birth attendant homes in Ikono, Akwa Ibom state, Nigeria.

\section{METHODS}

\section{Study design and area}

This research was a cross-sectional survey, made up of pregnant women at all stages of pregnancy attending antenatal clinics in traditional birth attendant homes within Ediene clan, Ikono Local Government Area of Akwa Ibom State, Nigeria. Ikono is bounded on the north by Ini Local Government Area, south by Abak and Uyo Local Government Areas, east by Itu and west by Ikot Ekpene Local Government Area. The Local Government Area have a landmass of 407.16 square kilometers; with a total population of 131,904 ; comprising 62,403 females and 69,501 males.

\section{Ethical considerations}

Ethical approval was obtained in accordance with the Helsinki declaration; from the Akwa Ibom State Ministry of Health Research Ethical Review Board, Uyo, Akwa Ibom State, Nigeria.

\section{Sample size estimation}

The sample size was estimated using the transformed formula as stated below by Kirkwood and Sterne. ${ }^{27}$ :

$\mathrm{N}=\frac{p q}{(B / 2) 2}=\underline{0.322 \times 0.678}=349$

\section{$(0.05 / 2)^{2}$}

Where $\mathrm{N}=$ Minimum sample size, $\mathrm{B}$ represent confidence interval, $5 \%=0.05$, p represent prevalence of pregnant women with asymptomatic bacteriuria. The prevalence of $32.2 \%$ was used in-line with the research carried out in Osuk-Ediene, Ikono, Akwa-Ibom state in a primary health facility. ${ }^{26}$ Therefore, the minimum sample size was 349 ; but it was rounded-up to 350 .

\section{Inclusion criteria}

All pregnant women not on antimicrobial drugs and no clinical symptoms of urinary tract infections visiting traditional birth attendant homes located in Ediene clan, 
Ikono Local Government Area of Akwa-Ibom State, Nigeria were recruited for this study.

\section{Exclusion criteria}

All pregnant women currently taking antibiotic drugs, traditional medicine that inhibit the growth of microorganism for treatment of urinary tract infection or any other type of illness for less than seven days were excluded from the study. Also pregnant women with clinical signs and symptoms of urinary tract infections were excluded. In addition, participants who refused to participate and/or fully cooperate with all guidelines of this study were excluded too. Uropathogens is said to be asymptomatic if the significant bacteria presence is $\geq 10^{5}$ $\mathrm{cfu} / \mathrm{ml}$ in two consecutive clean-voided mid-stream urine specimen in a patient without signs or symptoms. ${ }^{28}$

\section{Recruitment of participants}

Participants were recruited from traditional birth attendant homes residing within three villages namely Osuk-Ediene, Ikot Oku Ediene and Uyo Afiah Nkan; all in Ediene clan, Ikono Local Government Area of Akwa Ibom State, Nigeria. Written and informed consent was taken from the pregnant women who were ready to participate in the study and who fulfilled inclusion and exclusion criteria. The pregnant women were given the right to willingly continue or withdraw from the research. Information collected at each course of the study was kept confidential. Detailed history was taken including patient's age, address, marital status, educational status, occupation, monthly income rate, parity, gravidity, number of sexual partner, obstetric history, previous mode of treatment and duration of pregnancy. The information on gestational ages of pregnant women were used to classify them into 3 trimesters namely: first trimesters between 0-13 weeks, second trimesters between 14-27 weeks and third trimesters between 28-40 weeks. History regarding present ailments and use of medications or antibiotics in last 7days was also obtained. All recruited subjects were subjected to clinical examination, general and systemic examination by a qualified medical doctor. Based on other information obtained, participants were grouped into social classes 15 according to the method documented. ${ }^{29}$ Urine samples were collected from a total of 350 pregnant women visiting traditional birth attendants; residing within the jurisdiction of the research.

\section{Sample collection}

The recruited pregnant women were requested to clean their hands with soap and water; provided by the researchers. Then they were asked to clean their vulva and perineum with sterile cotton swab soaked in normal saline to reduce the risk of contamination. Clean catch mid-stream urine sample was collected using sterile, wide- mouthed glass bottles with screw cap top. The urine samples collected from participants were immediately taken to the laboratory for microbiological examination and biochemical testing. All urine samples were duly labeled and cultured on arrival (between 1-2 hours of collection). This was carried out to prevent bacterial population growth and proliferation in specimens.

\section{Urine microscopy}

Urine routine microscopy examination and urine culture sensitivity were carried out in the department of Medical Microbiology and Parasitology, Faculty of Clinical Sciences, University of Uyo, Uyo, Nigeria. The microscopy and cell count were carried out using the improved Neubaeur's haemocytometer. The haemocytometer was prepared for use by placing a clean grease free cover glass on the chamber and applying a gentle sliding pressure until a correct symmetrical positioning was achieved as indicated by the appearance of interference pattern (Newton's rings) as reported. ${ }^{30}$ Broken cover glasses were discarded, then un-centrifuged sample was mixed properly and using a clean Pasteur pipette, then the aspirated urine was filled into the counting chamber at $45^{\circ} \mathrm{C}$. Care was taken to avoid rapid filling, air bubbles and overflow, but if it happened, the chamber was washed and the step repeated. After filling the chamber, it was placed on the microscope stage for a few minutes before counting, this was carried out to enable the streaming of the fluid to stop and the cells settle on the bottom of the chamber.

A high dry magnification (objective $\mathrm{x} 40$ ) piece was used in counting. Cells touching the left hand and/or the upper lines of a square were counted, while those touching the lower and/or the right lines were considered outside the square. The leucocytes were distinguished from the nonsquamous epithelial cells using the larger and the nuclear orientation of the latter. The white blood cells (WBC) were counted in the 4 or 2 large squares.

\section{Urine culture-significant bacteriuria estimation}

Properly mixed urine specimens were cultured on Cystine Lactose Electrolyte Deficient (CLED) and blood agar for the primary isolation of uropathogens using a standard urine wire-loop ( $2 \mathrm{~mm}$ internal diameter) to deliver 0.05 $\mathrm{ml}$ of urine. Inoculated plates were incubated at $37^{\circ} \mathrm{C}$ for 24 hours. Bacteriuria was considered significant when at least 10 colony forming units of a single pathogen per milliliter of urine was counted $\left(10^{5} \mathrm{CFU} / \mathrm{mL}\right.$ of urine $){ }^{5}$ Observed colonies were sub-cultured until pure and distinct colonies were obtained. ${ }^{31}$

\section{Biochemical testing}

All biochemical tests were performed with pure, 24-hour old cultures. Negative and positive controls were included along with test specimens for the biochemical tests. The biochemical tests were carefully used to screen all isolates before further typing tests done. The methods 
were based on standard procedures for the identification of bacterial pathogens. ${ }^{31}$

\section{Antimicrobial susceptibility testing of uropathogens}

The antimicrobial susceptibility testing of all isolates was done using commercial disk following the standard disk diffusion method recommended by the National Committee for Clinical Laboratory Standards as documented. ${ }^{32}$

The drugs that were tested include Amoxicillin-clavulinic acid $(20 \mu \mathrm{g})$, Ceftazidine $(30 \mu \mathrm{g})$, Ceftriaxone $(30 \mu \mathrm{g})$, Azetronam $(30 \mu \mathrm{g})$, Ciprofloxacin $(5 \mu \mathrm{g})$, Nitrofurantoin $(300 \mu \mathrm{g})$, Cefotaxime $(30 \mu \mathrm{g})$, Imipenem $(10 \mu \mathrm{g})$, Sulfamethoxazole-trimethoprim $(1.25 \mu \mathrm{g})$, Azithromycin $(15 \mu \mathrm{g})$ and Gentamicin $(20 \mu \mathrm{g})$. All the antimicrobials agents used for the study were bought from Oxoid Limited, Cambridge, United Kingdom. All Culture media were tested for sterility and performance. Reference strains of E. coli ATCC 25922 and S. aureus ATCC 25923 were used during culture and antimicrobial testing of uropathogens from recruited subjects.

\section{Statistical analysis}

Information from laboratory findings and data collected using questionnaire were coded using Microsoft Excel Spreadsheet for subsequent statistical analysis. The coded data was analyzed using Statistical Package for Social Sciences (SPSS) version 20.0. Clinical, laboratory and quantitative data were compared using simple percentages and Chi-square $\left(\chi^{2}\right)$ test. Statistical significant was set at $5 \%$.

\section{RESULTS}

Urine samples were collected from a total of 350 pregnant women visiting traditional birth attendants (TBA) homes for antenatal clinics in Ediene clan, Ikono Local Government Area of Akwa-Ibom State, Nigeria. Out of the 350 pregnant women tested, 117 had asymptomatic bacteriuria giving a prevalence of $33.4 \%$. The mean age of the study participants was $26.21 \pm 3.6$ years (range 15-43 years). Majority of the participants were within the age range of 33-38 years $(33.1 \%)$ and $82.6 \%$ were married, while $2.3 \%$ were widows. Approximately $55.1 \%, 33.4 \%$ and $3.4 \%$ had primary education, informal education and tertiary education respectively. Multiparous, monoparous and nulliparous were $11.1 \%$, 54\% and $34.9 \%$ respectively, while $44.6 \%$ were in their third trimester period; with $15.8 \%$ positive for asymptomatic bacteriuria. Primigravidae was $28.9 \%$, $71.1 \%$ was multigravidae with $19.4 \%$ of positive for asymptomatic bacteriuria. There was significant association of age, educational status, parity, trimester period, occupation, number of sexual partner and monthly income with asymptomatic bacteriuria in the study population, while marital status was not significantly associated with the prevalence of asymptomatic bacteriuria (Table 1). The presence of abnormal conditions among the pregnant women recruited for the study was $6.3 \%, 8.9 \%, 9.4 \%, 10.9 \%$ and $13.1 \%$ for glycosuria, polymicrobial ASB, proteinuria/glycosuria, proteinuria and pyuria respectively (Table 2 ).

Table 1: Prevalence of ASB and demographic variables of recruited participants in Ikono.

\begin{tabular}{|c|c|c|c|c|c|}
\hline Variables & $\begin{array}{l}\text { Pregnant } \\
\text { No tested }(\%)\end{array}$ & $\begin{array}{l}\text { women } \\
\text { No negative }(\%)\end{array}$ & $\begin{array}{l}(\mathbf{N}=\mathbf{3 5 0}) \\
\text { No positive }(\%)\end{array}$ & $\mathrm{X}^{2}$ & P value \\
\hline \multicolumn{6}{|c|}{ Age (years) } \\
\hline $15-20$ & $21(6.0)$ & $11(3.1)$ & $10(2.9)$ & & \\
\hline $21-26$ & $83(23.4)$ & $65(18.6)$ & $18(5.1)$ & & \\
\hline $27-32$ & $102(29.1)$ & $55(15.7)$ & $47(13.4)$ & 1.926 & 0.371 \\
\hline $33-38$ & $116(33.1)$ & 87 (24.9) & $29(8.3)$ & & \\
\hline $39-43$ & $28(8.0)$ & $15(4.3)$ & $13(3.7)$ & & \\
\hline Total & $350(100)$ & $233(66.6)$ & $117(33.4)$ & & \\
\hline \multicolumn{6}{|c|}{ Marital status } \\
\hline Married & $289(82.6)$ & $198(56.6)$ & $91(26.0)$ & 0.786 & 0.984 \\
\hline Single & $36(10.6)$ & $26(7.4)$ & $10(2.9)$ & & \\
\hline Divorced & $17(4.9)$ & $6(1.7)$ & $11(3.1)$ & & \\
\hline Widowed & $8(2.3)$ & $3(0.9)$ & $5(1.4)$ & & \\
\hline \multicolumn{6}{|c|}{ Educational status } \\
\hline Informal & $117(33.4)$ & $71(20.3)$ & $46(13.1)$ & & \\
\hline Primary & $193(55.1)$ & $146(41.7)$ & $47(13.4)$ & 3.21 & 1.81 \\
\hline Secondary & $28(8.0)$ & $12(3.4)$ & $16(4.6)$ & & \\
\hline Tertiary & $12(3.4)$ & $4(1.1)$ & $8(2.3)$ & & \\
\hline \multicolumn{6}{|l|}{ Parity } \\
\hline Nullipara & $122(34.9)$ & $85(24.3)$ & 37 (10.6) & & \\
\hline Monopara & $189(54.0)$ & $130(37.1)$ & $59(16.9)$ & 1.27 & 0.429 \\
\hline
\end{tabular}

Continued. 


\begin{tabular}{|c|c|c|c|c|c|}
\hline Variables & $\begin{array}{l}\text { Pregnant } \\
\text { No tested }(\%)\end{array}$ & $\begin{array}{l}\text { women } \\
\text { No negative }(\%)\end{array}$ & $\begin{array}{l}(\mathbf{N}=\mathbf{3 5 0}) \\
\text { No positive }(\%)\end{array}$ & $\mathbf{X}^{2}$ & $P$ value \\
\hline Multipara & $39(11.1)$ & $18(5.1)$ & $21(6.0)$ & & \\
\hline \multicolumn{6}{|l|}{ Gravidity } \\
\hline Primigravidae & $101(28.9)$ & $52(14.9)$ & $49(14.0)$ & 1.69 & 1.106 \\
\hline Multigravidae & $249(71.1)$ & $181(51.7)$ & $68(19.4$ & & \\
\hline \multicolumn{6}{|l|}{ Trimester } \\
\hline $1^{\mathrm{st}}$ & $85(24.3)$ & $63(18.0)$ & $22(6.3)$ & & \\
\hline $2^{\text {nd }}$ & $109(31.1)$ & 69 (19.7) & 40 (11.4) & 3.061 & $1 . .981$ \\
\hline $3^{\text {rd }}$ & 156 (44.6) & $101(28.9)$ & $55(15.8)$ & & \\
\hline \multicolumn{6}{|l|}{ Occupation } \\
\hline House wife & 149 (42.6) & $104(28.9)$ & $45(12.9)$ & & \\
\hline Self-employed & $161(46.0)$ & $112(32.0)$ & $49(14.0)$ & 1.52 & 0.193 \\
\hline Employed & $27(7.7)$ & $10(2.9)$ & $17(4.9)$ & & \\
\hline Unemployed & $13(3.7)$ & $7(2.0)$ & $6(1.7)$ & & \\
\hline \multicolumn{6}{|c|}{ No. of Sexual partners } \\
\hline One & $299(85.4)$ & $197(56.3)$ & $102(29.1)$ & 3.102 & 1.290 \\
\hline Multiple & $51(6.8)$ & $36(10.3)$ & $15(4.3)$ & & \\
\hline \multicolumn{6}{|c|}{ Income/ Month (Naira) } \\
\hline No income & $13(3.7)$ & $7(2.0)$ & $6(1.7)$ & & \\
\hline$\leq \mathbb{N} 18,000$ & $149(42.3)$ & $80(22.9)$ & $69(19.7)$ & 2.86 & 0.331 \\
\hline$\geq £ 18,000$ & 188 (53.7) & 146 (41.7) & $42(12.0)$ & & \\
\hline
\end{tabular}

Table 2: Bacteriuria and the presence of abnormal conditions among recruited pregnant women in Ikono.

\begin{tabular}{|ll|}
\hline Abnormal conditions & No of positive samples (\%) \\
\hline Pyuria & $46(13.1)$ \\
\hline Glycosuria & $22(6.3)$ \\
\hline Proteinuria & $38(10.9)$ \\
\hline Proteinuria and glycosuria & $33(9.4)$ \\
\hline Monomicrobial ASB & $97(27.7)$ \\
\hline Polymicrobial ASB & $31(8.9)$ \\
\hline
\end{tabular}

Table 3: Frequency of ASB isolated in recruited participants in Ikono.

\begin{tabular}{|lll|}
\hline Microorganism & Number of Isolates & Percentage (\%) \\
\hline Escherichia coli & 35 & 29.9 \\
\hline Staphylococcus aureus & 19 & 16.2 \\
\hline Klebsiella pneumonia & 23 & 19.7 \\
\hline Pseudomonas aeruginosa & 12 & 10.3 \\
\hline Proteus spp & 10 & 8.5 \\
\hline Klebsiella spp & 8 & 6.8 \\
\hline S. saprophyticus & 10 & 8.5 \\
\hline Total & 117 & 100 \\
\hline
\end{tabular}

The most common asymptomatic bacteriuria isolates was E. coli 35(29.9\%), followed by Klebsiella pneumoniae with 23(19.7\%) and the least was other Klebsiella species with $8(6.8 \%)$ as shown in Table 3. Antimicrobial susceptibility pattern of Gram-negative and Grampositive asymptomatic bacteriuria isolates were observed among pregnant women visiting traditional birth attendant homes in Ikono are displayed on Table 4. Pseudomonas aeruginosa, a Gram-negative bacteria was more susceptible to gentamicin (92\%), Ciprofloxacin $(83 \%)$ imipenam $(83 \%)$ and azetronam $(75 \%)$.

The Staphylococcus saprophyticus a Gram-positive bacteria was more susceptible to imipenam (90\%), followed by gentamicin and ceftazidime at $80 \%$ (Table 4). A total of 117 uropathogenic isolates were tested for multidrug resistance. The highest multidrug resistance (MDR) was observed in Staphylococcus. saprophyticus (100-70\%) for azithromycine, azetronam, ceftriaxone, 
cefotaxime and sulphamethoxazole-trimethoprim when compared with the other isolates. The Gram-negative bacteria namely: Proteus species and Klebsiella species displayed high multidrug resistance between $60-90 \%$ for azetronam, gentamicin, sulphamethoxazole-trimethoprim, azithromycine, ceftriaxone and cefotaxime (Table 5).

Table 4: Susceptibility profile of ABS among recruited pregnant women isolates in Ikono.

\begin{tabular}{|c|c|c|c|c|c|c|c|c|c|c|c|}
\hline \multirow[b]{2}{*}{$\begin{array}{l}\text { Microorganism } \\
\text { (n) }\end{array}$} & \multicolumn{11}{|c|}{ Antimicrobial agent tested } \\
\hline & $\begin{array}{l}\text { CAZ } \\
\text { No } \\
(\%)\end{array}$ & $\begin{array}{l}\text { AMC } \\
\text { No } \\
(\%)\end{array}$ & $\begin{array}{l}\text { AZT } \\
\text { No } \\
(\%)\end{array}$ & $\begin{array}{l}\text { CRO } \\
\text { No } \\
(\%)\end{array}$ & $\begin{array}{l}\text { CIP } \\
\text { No } \\
(\%)\end{array}$ & $\begin{array}{l}\text { NIT } \\
\text { No } \\
(\%)\end{array}$ & $\begin{array}{l}\text { CTX } \\
\text { No } \\
(\%)\end{array}$ & $\begin{array}{l}\text { GEN } \\
\text { No } \\
(\%)\end{array}$ & $\begin{array}{l}\text { IPM } \\
\text { No } \\
(\%)\end{array}$ & $\begin{array}{l}\text { SXT } \\
\text { No } \\
(\%)\end{array}$ & $\begin{array}{l}\text { AZM } \\
\text { No } \\
(\%)\end{array}$ \\
\hline E. coli $(35)$ & $16(46)$ & $19(54)$ & $13(37)$ & $17(49)$ & $19(46)$ & $22(63)$ & $20(63)$ & $26(73)$ & $17(49)$ & $21(60)$ & $10(29)$ \\
\hline $\begin{array}{l}\text { K. pneumonia } \\
\text { (23) }\end{array}$ & $10(44)$ & $11(48)$ & $12(52)$ & $11(48)$ & $15(65)$ & $14(61)$ & $11(48)$ & $19(83)$ & $15(65)$ & $10(44)$ & $7(30)$ \\
\hline $\begin{array}{l}\text { P. aeruginosa } \\
\text { (12) }\end{array}$ & $6(50)$ & $8(67)$ & $9(75)$ & $6(50)$ & $10(83)$ & 7 (58) & $6(50)$ & $11(92)$ & $10(83)$ & $9(75)$ & $5(50)$ \\
\hline $\begin{array}{l}\text { Klebsiella spp } \\
\text { (8) }\end{array}$ & 7 (88) & $4(50)$ & $2(25)$ & $3(38)$ & $6(75)$ & $5(50)$ & $1(13)$ & 7 (88) & $8(100)$ & $4(50)$ & $1(13)$ \\
\hline Proteus spp (10) & $5(50)$ & $6(60)$ & $4(40)$ & $8(80)$ & $6(60)$ & $2(20)$ & $2(20)$ & $4(40)$ & $5(50)$ & $2(20)$ & $1(10)$ \\
\hline S. aureus (19) & $13(68)$ & $14(74)$ & $11(58)$ & $10(53)$ & $11(58)$ & $9(47)$ & $5(26)$ & $15(79)$ & $16(84)$ & $3(16)$ & $2(11)$ \\
\hline $\begin{array}{l}\text { S. saprophyticus } \\
\text { (10) }\end{array}$ & $8(80)$ & $6(60)$ & $1(10)$ & $2(20)$ & $7(70)$ & $5(50)$ & $3(30)$ & $8(80)$ & $9(90)$ & $3(30)$ & $0(0)$ \\
\hline
\end{tabular}

$\mathrm{CAZ}=$ ceftazidine, $\mathrm{AMC}=$ Amoxicillin - Clavulinic acid, $\mathrm{AZT}=$ Azetronam, $\mathrm{CRO}=$ Ceftriaxone $, \mathrm{CIP}=\mathrm{Ciprofloxacin}, \mathrm{NIT}=$ Nitrofurantoin, CTX $=$ Cefotaxime, GEN $=$ Gentamicin, IPM $=$ Imipenam, SXT $=$ Sulphamethoxazole-trimethoprim, $\mathrm{AZM}=$ Azithromycine.

Table 5: Antibiotic resistance in ASB isolated among pregnant women against different antimicrobial drugs.

\begin{tabular}{|c|c|c|c|c|c|c|c|}
\hline \multicolumn{8}{|c|}{ Microorganisms (n) } \\
\hline Drugs & $\begin{array}{l}\text { E. coli } \\
\text { (35) }\end{array}$ & $\begin{array}{l}\text { K. pneumonia } \\
(23)\end{array}$ & $\begin{array}{l}\text { Klebesiella } \\
\text { spp (8) }\end{array}$ & $\begin{array}{l}\text { P. aeruginosa } \\
\text { (12) }\end{array}$ & $\begin{array}{l}\text { Proteus } \\
\text { spp } \\
(10)\end{array}$ & $\begin{array}{l}\text { S. aureus } \\
\text { (19) }\end{array}$ & $\begin{array}{l}\text { S. } \\
\text { saprophyticus } \\
\text { (10) }\end{array}$ \\
\hline CAZ (\%) & $19(54)$ & $13(57)$ & $1(13)$ & $6(50)$ & $5(50)$ & $6(32)$ & $2(20)$ \\
\hline $\operatorname{AMC}(\%)$ & $16(46)$ & $12(25)$ & $4(50)$ & $4(33)$ & $4(40)$ & $5(26)$ & $4(40)$ \\
\hline AZT (\%) & $22(63)$ & $11(29)$ & $6(75)$ & $3(25)$ & $6(60)$ & $8(42)$ & $9(90)$ \\
\hline CRO (\%) & $18(51)$ & $12(25)$ & $5(63)$ & $6(50)$ & $2(20)$ & $9(47)$ & $8(80)$ \\
\hline CIP (\%) & $16(46)$ & $8(42)$ & $2(25)$ & $2(17)$ & $4(40)$ & $8(42)$ & $3(30)$ \\
\hline NIT (\%) & $13(37)$ & $9(38)$ & $3(38)$ & $5(42)$ & $8(80)$ & $10(53)$ & $5(50)$ \\
\hline CTX (\%) & $15(43)$ & $12(25)$ & $7(88)$ & $6(50)$ & $8(80)$ & $14(74)$ & $7(70)$ \\
\hline GEN (\%) & $9(26)$ & $4(60)$ & $1(13)$ & $1(8.3)$ & $6(60)$ & $4(21)$ & $2(20)$ \\
\hline IPM (\%) & $18(51)$ & $8(42)$ & $0(0)$ & $2(17)$ & $5(50)$ & $3(16)$ & $1(10)$ \\
\hline SXT (\%) & $14(40)$ & $13(57)$ & $4(50)$ & $3(25)$ & $8(80)$ & $16(84)$ & $7(70)$ \\
\hline $\operatorname{AZM}(\%)$ & $25(6.4)$ & $16(70)$ & $7(88)$ & $7(58)$ & $9(90)$ & $17(90)$ & $10(100)$ \\
\hline
\end{tabular}

$\mathrm{CAZ}=$ ceftazidine, $\mathrm{AMC}=$ Amoxicillin - Clavulinic acid, $\mathrm{AZT}=$ Azetronam, $\mathrm{CRO}=$ Ceftriaxone, $\mathrm{CIP}=$ Ciprofloxacin, $\mathrm{NIT}=$ Nitrofurantoin, $\mathrm{CTX}=$ Cefotaxime, GEN = Gentamicin, IPM = Imipenam, SXT = Sulphamethoxazole-trimethoprim, AZM = Azithromycine.

\section{DISCUSSION}

Urinary tract infection is a severe threat in our locality, especially to pregnant women living in both urban and rural areas. ${ }^{10,25-26}$ Asymptomatic bacteriuria is a frequently occurring bacterial infection of the urinary tract that requires medical treatment even during pregnancy. Therefore, there is need to constantly monitor the prevalence of uropathogens causing infection in pregnant women in order to prevent complications associated with its occurrence through prompt medical treatment. In this present study, the prevalence of asymptomatic bacteriuria was $33.4 \%$; using 350 pregnant women attaining antenatal care at traditional birth attendant homes in Ikono. This prevalence rate in our present study is similar to documented research in Akwa Ibom State and Lahore, Pakistan, among pregnant women that were asymptomatic..$^{25,26,33}$ In contrast, higher prevalence of $45.3 \%$ was observed among pregnant women visiting health facility in Benin and $55 \%$ for those visiting traditional birth attendant home in Benin city, $83 \%$ in Nagpur, a rural settlement in India. ${ }^{29,9,31}$ A low 
prevalence of $19 \%$ was reported in Akwa Ibom state among pregnant women visiting a federal government health facility in Uyo when compared with $33.4 \%$ recorded in this present study in Ikono, Akwa Ibom State, Nigeria. ${ }^{26}$ Also $19.9 \%$ was reported in Harar, Ethopia, $18.8 \%$ in Southern Ethiopia, $17.8 \%$ in Ambo town, Central Ethopia, 16.9\% in Addis Ababa, Ethiopia, 10.3\% in Jos, Nigeria, and $8.9 \%$ in Northern Tanzania. ${ }^{7,28,34-37}$ Other documented study reported a lower prevalence of $7.8 \%$ among hospitalized pregnant women having ASB in Ankara, Turkey, whereas $5.7 \%$ was seen in Douala, Cameroon, $4.5 \%$ in Bangladesh, India, and $3.7 \%$ in Mbale; Eastern Uganda among pregnant women visiting orthodox clinics for antenatal care. ${ }^{2,23,38,39}$ The varying prevalence of ASB among pregnant women from one country to another and among regions of the same country might be due to difference in risk factors associated with a particular geographical region and the methodology adopted by different researchers. Also the women in low socioeconomic status; residing in rural areas might be practicing poor hygiene. These will increase the risk of developing urinary tract infections. The mean age in this present study was 26.21 \pm 3.6 years and this mean age is in tandem with other reported studies in some African countries, and in an Indian population. ${ }^{7,23,28,34-35,37,31}$

Age, educational status, parity, gravidity, trimester period, number of sexual partner, occupation and monthly income rate were significantly associated with prevalence of ASB in our population. Poor hygiene practices were observed in first time mothers of young age and those with low educational attainment; especially in this rural areas where the study was investigated. This is in harmony with the results reported by Lee et al., in India, and in South-south Nigeria, but there was no significant association of trimester to the prevalence of ASB in Southern Ethiopia; income rate, parity, gestational age, marital status and age of pregnant women; which disagree with our results in this study..$^{34,25,26,7,23}$

Proteinuria, glycosuria, pyuria and bacteriuria were some abnormal conditions observed among pregnant women recruited in our study; although we didn't assess statistical relationship of these conditions to the prevalence of ASB. These abnormal conditions were also reported in previous documented studies in Nigeria agreeing to the result of this study. ${ }^{10,25-26}$ Pyuria were detected in these women because they may have had coinfection with Chlamydia, urogenital tuberculosis and renal myco-bacterial infections. Bacteriuria may be present without pyuria due to contamination or inappropriate collection of the sample, production of leucocyte destroying enzyme by bacteria (leukocidin by Staphylococcus aureus), neutropaenia (people with poor cell-mediated immune response) while gestational proteinuria and glycosuria may be due to physiological challenges of pregnancy not related to the presence of bacterial infections. These are in-line with other reports. ${ }^{2,3,10,25,26}$ Glycosuria can also happen in pregnant woman if they develop gestational diabetes during pregnancy. It is a predisposing cause of vaginal thrush and glycosuria was one of the abnormal condition detected in some pregnant women in our study; pointing to the fact that it might cause vaginal thrush in some of them. ${ }^{3}$ Although glycosuria was not investigated as a predictive factor for causing vaginal thrush in this study.

Escherichia coli was the most abundant uropathogen with an overall isolation rate of $29.9 \%$ and followed by Klebsiella pneumonia (19.7\%). Other findings have been reported in Turkey, Ethiopia, Cameroon, NigeriaPakistan, and India where Escherichia coli and Klebsiella pneumoniae were the first and second most prevalent pathogens. . $^{2,28,34-35,23,9,25,26,33,31,38}$ Some authors reported Staphylococcus species or Streptococcus pyogenes to be the second most common uropathogen; but accounting for the third cause of bacteriuria in our study. Variation in geographical location, uses of antibiotic with or with-out prescription by qualify medical personnel are common in rural and urban settlements which may have accounted for these differences. ${ }^{10,36-37}$

Some Gram-negative and Gram- positive asymptomatic bacteriuria isolates were susceptible to antimicrobial drugs in varying degree; from our results in this study. For instance Pseudomonas aeruginosa (Gram-negative bacteria) was more susceptible to seven antimicrobial drugs namely: gentamicin (92\%), Ciprofloxacin (83\%) imipenam $(83 \%)$ and azetronam (75\%), sulphamethoxazole-trimethoprim $(75 \%)$, amoxicillin clavulinic acid $(67 \%)$ and nitrofurantoin $(58 \%)$, while Staphylococcus saprophyticus (Gram-positive bacteria) was more susceptible to imipenam $(90 \%)$, followed by gentamicin and ceftazidime at $80 \%$. These finding were similar to the documented study in Benin City, Akwa Ibom, and Indiawere majority of E. coli isolates, some Pseudomonas aeruginosa, Staphylococcus saprophyticus, etc were sensitive to gentamicin, sulphamethoxazoletrimethoprim, nitrofurantoin, norfloxacin, imipenem, etc which are commonly used antibiotics. ${ }^{9,25,26,31,38}$

In South Africa, various microorganisms were susceptibility to different antimicrobial drugs like amoxicillin-clavulanic acid, cefuroxime, ceftriaxone, nitrofurantoin and ciprofloxacin, trimethoprimsulfamethoxazole in different degrees (approximately between $100-67 \%$ ), which is relatively similar to our findings in this study conducted in Ikono. ${ }^{40}$ Also similar drug sensitivity pattern was found to be $67 \%$ to $55 \%$ for some antimicrobial drugs like imipenem, etc against some uropathogens including Escherichia coli, Klebsiella species, Pseudomonas species, Staphylococcus species, etc, as reported in Lahore, Pakistan. ${ }^{33}$ In our present study, the highest multidrug resistance (MDR) was observed in both gram positive and negative isolates like Staphylococcus saprophyticus, Proteus species and Klebsiella species between 100-60\%. 
This is in concomitant to the findings in Pakistan in which the highest MDR was observed in Klebsiella species and other microorganisms. ${ }^{33}$ Also similar finding to our present study was highlighted by Nteziyaremye et $a l$., in Eastern Uganda where some isolates were found to have a high level of multidrug resistance especially for Pseudomonas species, Klebsiella species and Staphylococcus aureus. ${ }^{39}$

\section{CONCLUSION}

The prevalence of urinary tract infection among pregnant women visiting traditional birth homes for antenatal clinic was $33.4 \%$, using 350 participants. Age, educational status, parity, gravidity, trimester, occupation, number of sexual partners and monthly income rate were significant predictors of ASB in pregnant women. Escherichia coli were the most predominant bacterial isolates followed by Klebsiella pneumonia and some of the isolates were resistant to azithromycine, cefotaxime, and nitrofurantoin.

Susceptibility were detected against Gentamicin, imipenem, ciprofloxacin, ceftriaxone and hence could be used as empirical therapy for UTI in the study area. Multi-drug resistant were widespread in most of the isolates. Health education, continuous and collaborative surveillance of ASB and antimicrobial resistance pattern are essential to reduce the consequence of asymptomatic bacteriuria and multi-drug resistant bacteria in pregnant women.

Health education of antenatal populations in traditional birth homes and traditional birth attendants by government and/or other intervention agencies are strongly recommended.

\section{ACKNOWLEDGMENTS}

Authors are thankful to Dr. Ekpo, Paul Bassey, Head of the Department of Genetics and Biotechnology, Faculty of Biological Sciences, University of Calabar, Nigeria for his outstanding technical, linguistic guidance and support. The encouragement and constructive criticism of $\mathrm{Mr}$. Godwin Akpan is highly appreciated.

We also expressed our profound gratitude to all pregnant women who willingly participated in this research. The traditional birth attendants are appreciated too for allowing conducive environment within their homes for the research.

\section{Funding: No funding sources}

Conflict of interest: None declared

Ethical approval: The study was approved by the Institutional Ethics Committee Akwa Ibom State Ministry of Health Research Ethical Review Board, Uyo, Akwa Ibom State

\section{REFERENCES}

1. Kamgang FdPS, Maise HC, Moodley J. Pregnant women admitted with urinary tract infections to a public sector hospital in South Africa: Are there lessons to learn? South Afr J Infect Dis. 2016;31(3):79-83.

2. Beksac AT, Orgul G, Tanacan A, Uckan H, Sancak B, Portakal O, Beksac MS. Uropathogens and Gestational Outcomes of Urinary Tract Infections in Pregnancies that Necessitate Hospitalization. Current Urol. 2019;13:70-3.

3. Matuszkiewicz-Rowińska J, Małyszko J, Wieliczko M. Urinary tract infections in pregnancy: Old and new unresolved diagnostic and therapeutic problems. Arch Med Sci. 2015;11(1):67-77.

4. Sibi G, Kumari P, Kabungulundabungi N. Antibiotic sensitivity pattern from pregnant women with urinary tract infection in Bangalore, India. Asian Pac J Trop Med 2014; 7(Suppl 1):S116-S120.

5. Ade-Ojo IP, Oluyege AO, Adegun PT, Akintayo AA, Aduloju OP, Olofinbiyi BA. Prevalence and antimicrobial susceptibility of asymptomatic significant bacteriuria among new antenatal enrollees in south west Nigeria. International Research Journal of Microbiol. 2013;4(8):197-203.

6. Jennifer P, Cyril R, Piyumi P, Nimesha, G, Renuka J. Asymptomatic bacteriuria in pregnancy; Prevalence, risk factors and causative organism. Sri Lanka Journal of Infectious Diseases. 2012;1(2):42-6.

7. Tadesse E, Teshome M, Merid Y, Kibret B, Shimelis T. Asymptomatic urinary tract infection among pregnant women attending the antenatal clinic of Haussa referral hospital, Southern Ethiopia. BioMed Cental Res Note. 2014;7(155):1-5.

8. Assefa A, Asrat D, Woldeamanuel Y, G/Hiwot Y, Abdella A, Melesse T. Bacterial profile and drug susceptibility pattern of urinary tract infection in pregnant women at Tikur Anbessa Specialist Hospital, Addis Ababa, Ethiopia. Ethiopia Medical J. 2008;46:227-35.

9. Oladeinde BH, Omoregie R, Oladeinde OB. Asumptomatic urinary tract infection among pregnant women receiving ante-natal care in a traditional birth home in Benin City, Nigeria. Ethiop Journal of Health Sci. 2015;25(1):3-8.

10. Akpan NG, Onwuezobe IA, Antia UE. Asyptomatic bacteriuria among pregnant women at University Hospital in Uyo, Nigeria: Prevalence, risk factors and characteristics. Asian J Medic Health. 2017; 3(3):1-9.

11. Nyanzi S, Manneh H, Walraven G. Traditional Birth Attendants in Rural Gambia: Beyond Health to Social Cohesion. African Journal of Reproductive Health. 2007;11(1):43-56.

12. Gambia and UNICEF. Situation analysis of children and women in The Gambia. Banjul: UNICEF, 1997. WHO; UNFPA; UNICEF. Traditional Birth Attendants; WHO: Geneva, Switerland, 1992; 
Available

https://apps.who.int/iris/handle/10665/38994.

13. Ogbo FA, Trinh FF, Ahmed KY, Senanayake Y, Rwabilimbo AG, Uwaibi NE, et al. Global Maternal and Child, Health Research Collaboration (GloMACH). Prevalence, Trends, and Drivers of the Utilization of Unskilled Birth Attendants during Democratic Governance in Nigeria from 1999 to 2018. Int. J. Environ. Res. Public Health, 2020;17: 372-498.

14. Ahmed OA, Odunukwe NN, Akinwale OP, et al. Knowledge and practices of traditional birth attendants in prenatal services in Lagos State, Nigeria. Afr J Med Sci. 2005; 34(1):55-58.

15. Tsui AO, Wasserheit JN, Haaga JG, eds. Reproductive Health in Developing Countries: Expanding Dimensions, Building Solutions. Washington DC: 1996.

16. Imogie OI. The practice of traditional birth attendants and women's health in Nigeria. 25th Congress Medical Women's International Association. 2000. Available from: http://www.regional.org.au/au/mwia/ papers/full/28_imogie.htm. Accessed January 16, 2012.

17. Idowu OA, Mafiana CF, Sotiloye D. Rhesus negative pregnant women in a traditional birth home in Abeokuta, Nigeria. Afr J Biotechnol. 2003; 2(8):2413.

18. Renkert ND. Opportunities to improve maternal health literacy through antenatal education: an exploratory study. Health Promot Int. 2001;16(4):381-8.

19. Abdel-Aziem AA, Duria AR, Ameer OA, Ishag A. Awareness of danger signs and nutritional education among pregnant women in Kassala, Eastern Sudan. Sudanese J Public Health. 2010;5:179-81.

20. Sadoh AE, Ogungbe RO. Multiple fractures and latrogenic burns in a Newborn due to unskilled Delivery: A case Report. Afr J Reprod Health. 2008;12(3):197-206.

21. Babalola S, Fatusi A. Determinants of use of maternal health services in Nigeria-Looking beyond individual and household factors. BMC Preg Child Birth. 2009;9:43-5.

22. Ndidi EP, Osaremen IG. Reasons given by pregnant women for late initiation of antenatal care in the Niger Delta. Nigeria. Ghana Med J. 2010;44(2):4751 .

23. Nguefack CT, Ebongue CO, Chokotheu CN, Ewougo CE, Njamen TN, Mboudou E. Clinical presentation, risk factors and pathogens involved in bacteriuria of pregnant women attending antenatal clinic of 3 hospitals in a developing country: a cross sectional analytic study. BMC Pregnancy and Childbirth. 2019;19:143-9.

24. Ebuehi OM, Akintujoye IA. Perception and utilization of traditional birth attendants by pregnant women attending primary health care clinics in a rural Local Government Area in Ogun State, Nigeria. International J of Women's Health. 2012;4:25-34.

25. Akpan NG, Umoyen AJ, Luka TT, Onwuezobe IA, Antia UE, Okon AS. Asyptomatic uropathogenic bacteriuria among pregnant women and nonpregnant women at St Luke,s hospital Anua, Offot Ukwa District Uyo: a reassessment case-control approach. American J Laboratory Medic. 2019; 4(1):1-10.

26. Akpan NG, Umoyen AJ, Luka TT, Esua IS, Okon AS Antia UE. Bacterial Etiologic agents, Prevalence and Associated Risk Factors of Asymptomatic Bacteriuria among Pregnant and Non-pregnant Women in Primary Health Care Centers in SouthSouth Nigeria. International J. of Med and Health Res. 2019;5(6):66-76.

27. Kirkwood BP, Sterne JAC. Sample size Calculation. In: essential medical statistics ( $2^{\text {nd }}$ Edition). Blackwell Science Limited, Massachusetts, United States of American. 2003:413-28.

28. Gessese YA, Damessa DL, Amare MM, Bahta YH, Shifera AD, Tasent FS, et al. Urinary pathogenic bacteria profile, antibiogram of isolates and associated risk factors among pregnant women in Ambo Town, Central Ethiopia: A cross-sectional study. Antimicrobial Resistance and Infection Control. 2017;16(132):1-10.

29. Imade PE, Izekor PE, Eghafona NO, Enabulele OI, Onyeagba OI, Ophori E. Asymptomatic bactereriuria among pregnant women. North American J Medic Sci. 2010;2:263-6.

30. Hoberman A, Wald ER, Reynolds EA, Penchansky L, Charron M. Pyuria and bacterieuria in urine specimens obtained by catheter from young children with fever. J Pediatr. 1994;24:513-9.

31. Sadhvi K, Kose V. Frequency of urinary tract infections among pregnant women receiving antenatal care in a tertiary care centre: hospital based cross-sectional study. Int J Reprod Contracept Obstet Gynecol. 2021;10(1):207-14.

32. National committee for Clinical Laboratory Standards (Clinical Laboratory Standard Institutes). Performance of standard for antimicrobial disk susceptibility test: Approved standards. M2 - A7. PA USA: NCCL Villanova, 2012; 32(1).

33. Asmat U, Mumtaz MZ, Malik M. Rising prevalence of multidrug-resistant uropathogenic bacteria from urinary tract infections in pregnant women. Journal of Taibah University Medical Sciences, 2020.

34. Edae M, Teklemariam Z, Weldegebreal F, Abate D. Asymptomatic Bacteriuria among Pregnant Women Attending Antenatal Care at Hiwot Fana Specialized University Hospital, Harar, Eastern Ethiopia: Magnitude, Associated Factors, and Antimicrobial Susceptibility Pattern. International J Microbiol, 2020;8:1-8.

35. Wabe YA, Reda DY, Abreham ET, Gobene DB, Ali M M. Prevalence of Asymptomatic Bacteriuria, Associated Factors and Antimicrobial Susceptibility Profile of Bacteria Among Pregnant Women 
Attending Saint Paul's Hospital Millennium Medical College, Addis Ababa, Ethiopia. Therapeutics and Clinic Risk Management. 2020;16:923-32.

36. Banda JM, Cletus D, Sheyin Z, Junaid SA, John B, Mohammed SSD, Damen JG. Prevalence of asymptomatic Bacteriuria among Pregnant Women Attending Antenatal Clinic at Plateau State Specialist Hospital, Jos, Nigeria. Arch Microbiol Immunol. 2020;4(3):121-30.

37. Mwei M. K, Mchome B, John B, Maro E. Asymptomatic bacteriuria among women attending antenatal clinic at Kilimanjaro Christian Medical Centre in Northern Tanzania. Clin. Pract, 2018; 15(6): 917-922.

38. Lee ACC, Mullany LC, Koffi AK, Rafiqullah I, Khanam R, Folger LV, et al. Urinary tract infections in pregnancy in a rural population of Bangladesh: population based prevalence, risk factors, etiology, and antibiotic resistance. BMC Pregnancy and Childbirth. 2020;20:1-11.
39. Nteziyaremye J, Iramiot SJ, Nekaka R, Musaba M. W, Wandabwa J, Kisegerwa E, et al. Asymptomatic bacteriuria among pregnant women attending antenatal care at Mbale Hospital, Eastern Uganda. Plos One. 2020;15(3):19-31.

40. Bhola P, Mvelase NR, Balakrishna Y, Mlisana KP, Swe-Han KS. Antimicrobial susceptibility patterns of uropathogens isolated from pregnant women in KwaZulu-Natal Province. 2011 - 2016. S Afr Med J, 2020;110(9):872-6.

Cite this article as: Umoyen AJ, Akpan NG, Sunday CJ, Ekpenyong BB. Uropathogens and antimicrobial susceptibility profiles of asymptomatic bacteriuria among pregnant women receiving antenatal care in traditional birth attendants homes in Ikono, AkwaIbom State, Nigeria. Int J Reprod Contracept Obstet Gynecol 2021;10:1337-46. 